\title{
Conquered Populations in Early Islam: Non-Arabs, Slaves and the Sons of Slave Mothers
}

\section{ELIZABETH URBAN}

Edinburgh: Edinburgh University Press, 2020. 227 pp.

'Ațā' [b. Abī Rabāḥ, d. c. 114/732] said, "A man used to permit his female slave to his male slave (ghuläm), his son, his brother or his father, and [likewise] a woman [her female slave] to her husband. I do not like this to be done ( $m \bar{a} u$ uhibb an yuf'al dhālik), nor have I heard that anyone of repute [would do so]. It has reached me that a man used to send his female slave to his guest [for purposes of sexual hospitality]."

Ṭāwūṣ [d. 106/724] used to see no harm [in a wife lending her slave woman to her husband for sex]: "It is licit (haläl), and if the slave woman gives birth, her child is free, and the slave woman [still] belongs to the wife. Her husband is not punished at all (lā yugharram zawjuhā shay'āa)."2

'Umar [d. 23/644] was informed [that a woman had committed illicit sex]; he asked her [if the accusation was true]. She 
answered, "I was a poor woman (miskina) with nobody to fend for me, so I had only myself [to rely on, i.e. prostitution]..." [After confirming the truth of her account, 'Umar] had her flogged with a hundred [stripes], then gave her provisions and clothing ( $a^{\dagger} t \bar{a} h \bar{a}$ wa kasāhā) and ordered her travelling-companions to take her back with them [to the Yemen]. ${ }^{3}$

It is not permissible to sell [the umm al-walad] unless her master is indebted - and then at her sale-price-and he does not possess other property [with which to repay the debt]... if the child dies, it is permissible to sell or gift [the umm al-walad] or to do anything else [that one normally does with property]. ${ }^{4}$

In the wake of the Conquests, Muslims constituted a tiny elite of no more than half a million ruling over a sprawling empire whose subjects numbered between forty and sixty times that number. ${ }^{5}$ The story of early Islamic society is therefore, above all else, a story of the integration and "Islamization" of huge populations of outsiders. Given this radical numerical disparity, one is prompted to wonder about the mechanisms that incorporated outsiders into the social fabric of the umma. Elizabeth Urban's illuminating Conquered Populations in Early Islam engages with this question at length, tracing the relevant assimilatory trajectories with careful attention to the source material in lucid, engaging prose. She explores three key sets of outsider populations and their contested paths to integration: the mawāli ("non-Arabs"), jawāar (slave-concubines), and hujanä' (children of non-Arab concubines). Her book is organized into five main chapters, on mawāli and enslaved women in the Qur'ān; the freedman Abū Bakra (d. 52/672); enslaved prostitutes; slave-concubines and their sons, and finally, singing slave women (qiy $\bar{a} n$ ) and the non-Arab element of the secretarial class $(k u t t \bar{a} b)$. Before proceeding, I must point out that Urban assumes the truth of two highly controversial theses from the outset: Donner's "Believers" thesis and Peter Webb's claims about the Umayyad origins of Arab identity (4-5). ${ }^{6}$ One expects that by stating 
these commitments in the introduction, Urban hopes to insulate any consequent arguments from criticism. Fair enough; one cannot devote a book addressed to another subject entirely to demonstrating the plausibility of either idea. On the other hand, sound buildings require solid foundations. To her credit, I think, Urban avoids dwelling on these problems and quickly turns her focus to the "meat" of the book. She even seems to step back from some of the more radical claims of Donner: "I do not wish to overstate the case. I do not mean to say that the Umayyads invented the term 'Muslim'... Islam is clearly a Quranic term that may be a proper name for the religion" (184). ${ }^{7}$ In any case, the result is a generally impressive, thoughtful, and certainly important contribution to the existing scholarship. I would not hesitate to assign most of its chapters to my graduate and undergraduate students, or to recommend the book to colleagues.

My main concern with Conquered Populations is its studied neglect of Islamic law. It might be objected that there are other important disciplines, and other genres of source material at least as worthy of consulting in a study of this sort. That is certainly true. But slavery is, ultimately, a legal category. Urban's scope is broad and she prefers to write of "unfreedom" (6), which encompasses the whole spectrum from enslaved persons to freedmen and others subject to various forms of coercion. She insists that "legal material... tells us little about the earliest experiences of slaves in the umma, the different occupations slaves held, the actual practice of buying and selling slaves," and more (8). Even if that were true (and at best her case is seriously overstated), it would not justify altogether ignoring legal material, which the author seems to do. Nor does it explain her choice to dwell at much greater length on early tafsìr literature (in chapters two and four), which is evidently much less useful than fiqh on all of these points. Leaving aside the numerous important studies that have established that a careful reading of legal texts can in fact tell us quite a lot about early Muslim society, ${ }^{8}$ or that the historicity of some of the earliest and most valuable material has been demonstrated persuasively, ${ }^{9}$ at the very least one must be aware that the sheer volume of extant early fiqh literature dwarfs tafsir by 
a considerable degree. ${ }^{10}$ By virtue of this point alone, it is likely to contain more relevant and useful information. Urban complains for example that early tafsì literature does not "engage with the possibility that prostitutes might struggle with economic hardship or limited personal agency" (35), later recognizing that this may be a problem of genre (36). Frankly, it is; and figh is far less constrained, in this respect (see epigraph three). Legal texts also invalidate the strange claim (based on her reading of the tafsir literature) that "any woman who continues to be a prostitute must 'want' to be a prostitute and thus deserves whatever exploitation or injustice she experiences" (94). Far from it. When Urban does discuss discrete points of law, most of her claims are either over-generalized or (in a minority of cases) simply wrong: e.g., that "lawyers decreed that no Muslim or Arab could be reduced from a state of freedom to a state of slavery" (6), ${ }^{11}$ or the repeated claim that Imāmī-Shī ${ }^{-1}$ jurists permitted the unrestricted sale of ummahāt al-awlād (7, 117: see epigraph four). The most unfortunate aspect of this neglect is that figh works furnish the sort of evidence that would have bolstered the arguments Urban makes in a number of places: e.g., her observation that there "is some historical evidence suggesting that early Islamic men [sic] sometimes took their wives' slaves as their own umm walads" (119, see epigraphs one and two and fn. 13, below). It would have also perhaps dispelled her skepticism about other reports, e.g., on the "supposed pre-Islamic practice of providing a slave girl to pleasure a guest" (emphasis mine, 88). There is no good reason to doubt the broad accuracy of the account; "sexual hospitality" of this kind is attested in a wide range of early sources and is well known to travellers and others (more recently, anthropologists) in Arabia down to the modern period. ${ }^{12}$ It is also known from early figh (see epigraphs one and two). The view permitting the "lending out" of one's slave women for sex is defended in seminal classical Twelver-Shī' 1 i works. ${ }^{13}$ While it is scarcely feasible for any study to survey all of the relevant sources, it is wrong to suggest that legal materials are of limited value. Quite the opposite: they provide crucial context for several of the questions explored in the book, 
and the lack of engagement with figh should be acknowledged as a serious limitation.

One other concern — on which some readers may disagree with me-is the book's ritualized moral hand-wringing. E. P. Thompson once famously warned historians of the dangers of the "enormous condescension of posterity." 14 There is, unfortunately, rather a lot of it here. Urban reassures readers that she "does not condone the sentiment" of a hadīth reported by Abü Bakra (75); the exegetes are similarly condemned for "failing to interrogate the unjust systems [i.e. slave prostitution] of their own making" (98), and so on. How meaningful, really, is this critique? How are premodern Qur'ān commentators responsible for prostitution? If the answer is that they upheld patriarchy in various ways, which they surely did, is the accusation not really that they failed to share the author's views? ${ }^{15}$ Much more problematically, this moralizing approach to the sources seems to guide a number of dubious inferences made in the book. Urban recognizes certain accounts of slave prostitutes in the tafsīr literature as possessing historicity, for example, partly because their behavior conforms to feminist expectations of agency. These narratives focus on particular female slaves' refusal to engage in prostitution, "not on how the men treat her or how Islam saves her," and the stories therefore contain a ring of truth (82-83). These objections aside, Urban would have benefitted greatly from Hina Azam's magisterial Sexual Violation in Islamic Law. It is, in my opinion, easily the single most important study of Islamic sexual mores ever published, and it contains much excellent reflection on the subject (including early attitudes towards prostitution).

Urban is on much firmer ground when she mines the biographical literature for information on slave-concubines (using the Tabaqāt of Ibn Sa d, d. 230/845), qiyān and non-Arab kuttāb (using the Kitāb al-Wuzarā' wa l-kuttāb of al-Jahshiyārī, d. 331/942, among other sources). These chapters - five and six, respectively_are the best in the book, and they are models of careful erudition, among the best uses of digital humanities techniques I have read in the field. She demonstrates that ummahät al-awläd were most widely found 
among the Quraysh (117), that they were never as common as (free) wives (113-114), and that there was a precipitous drop in the use of slave-concubines to produce children in the period immediately preceding the Abbasid revolution (112). Urban also finds that prejudice does not satisfy as an explanation for the absence of slave-born caliphs in the Umayyad period. This dearth owes more to the lack of powerful maternal connections enjoyed by such persons (125), a social fact that became less relevant over time with the diminishing importance of tribal ties. Similarly, as ruling families became more powerful, and their marriage patterns correspondingly more endogamous, the establishment of the children of slave-concubines as rulers became more appealing. Concubinage "solidifies political power...within one clan or extended family" (127). The realization that Arabs as descendants of Hagar were, in effect, all the offspring of slavery helped to defuse the criticism that maternal non-Arab blood vitiated one's lineage. The outstanding learning and piety of some such children was also typically seen (in a number of sources) as having the same effect: the children of foreign slave-concubines ultimately proved themselves to be good Muslims (124).

Urban's observations on qiyān and kuttāb are equally insightful, and no less well-evidenced. I shall focus my remarks on the latter. She finds that non-Arab secretaries were prominent in certain parts of the Umayyad bureaucratic apparatus, particularly tax collection (dīwān al-kharāj), the chancery ( $\operatorname{i} \bar{w} w \bar{a} n$ al-rasà $i l)$, and the office of the royal seal (khätim). Higher posts, such as provincial governorships, tended to be entrusted to Arabs (154-155). Again, there is a noticeable decline in the use of mawāl $\bar{\imath}$ in the state bureaucracy in the two decades immediately preceding the Abbasid revolution. This part of the book can be profitably read alongside Luke Yarbrough's Friends of the Emir, which corroborates important elements of Urban's analysis. ${ }^{16}$

Conquered Populations also makes a number of interesting interventions in tafsir studies. Some of these challenge, while others broadly complement, the understandings of premodern commentators, whose "viewpoints are not the only valid ones" (36). Most controversially, Urban claims that Q. 24:33-traditionally 
understood to prohibit masters from compelling their slave women into prostitution - may instead mean that slave women were given the option of refusing their masters' sexual advances in order to remain "chaste" (in aradna tahașșunān). The fatayāt referred to in the verse are then "a specific subset of young, unmarried, believing righteous slaves" (30) who could opt for celibacy outside of marriage for pious considerations. Urban asks, along with some commentators, how it could be possible (according to the traditional view) to describe a woman who did not desire tahașșun as compelled to prostitution (35). This is a good question, and it identifies a clear problem with the conventional understanding of the verse; but Urban's interpretation (one of two she suggests) is a case of the cure being worse than the disease. It involves her in quite serious self-contradiction, for she accepts the facticity of (some of) the sabab nuzu $l$ accounts relating the verse to prostitution later on in the book (82-85). Urban also readily concedes that the Qur'ān contains passages that "allow male masters to practice concubinage with their female slaves," seemingly without restriction (30). She attempts to distinguish the permissibility of such relations from the masters' as opposed to the slaves' perspectives; verses making it licit only do so addressing masters, we are told. The Qur'ān, in her reading, seems to contain two more or less mutually exclusive teachings on the subject, addressed to masters and to their female slaves, respectively. Later on Urban suggests that her novel reading was dismissed out of hand by exegetes, "not because it is textually unsupportable" (36), but because slave-owning, patriarchal commentators unsurprisingly came down on the side of hierarchy. This is, frankly, an appeal to shared ideology that ignores the obvious problems (not least, the contradictions) within the novel view itself. ${ }^{17}$ But the novel reading is only one interpretation offered by Urban (29); the first is, basically, conventional, and is far more plausible (and not for that reason, as we have seen).

Building on her more compelling insights on Q. 33:5 (20-24), Urban argues that changing views of the status of the freedman Abu Bakra reflect shifting relations of power within the Muslim 
community. A careful sifting of the sources suggests that "Abū Bakra was not a mawlā of the Prophet, or even a mawla at all" (50). Instead, he was first referred to exclusively as the "freedman of God" (tali $q$ Allāh), a term that reflects his daring escape from the pagans to the Prophet's camp at the siege of T⿳ă if. While some social arrangements may have been made to ensure Abū Bakra's smooth integration into the umma, he remained nonetheless master of his own self, like the later legal category of the $s \bar{a}^{\prime} i b a$ (rejected by most jurists), the patron-less former slave (54). Abū Bakra's identification as a mawla (i.e. client), usually of the Prophet, reflects later debates about the vices of the Umayyads, in particular the notorious Ziyād b. Abīh (Abū Bakra's half-brother, d. 53/673). In these debates, Abū Bakra's proud identification as a mawla makes him the pious foil to the worldly Ziyād, with his false claims to Arab lineage (as the supposed son of Abū Sufyān, 57-58). Several accounts do report Abū Bakra's true father; the hadith specialists, on the other hand, view Abū Bakra straightforwardly as the son of his mother's master, al-Hārith b. Kalada (the Companion reported to have studied medicine at Gundeshapur, d. 13/634-5). This is because of their commitment to the principle, embodied in the form of a hadith, that "the child belongs to the [master of the] bed (al-walad li-l-firāsh)." Urban states that the hadith scholars claimed they "knew better" about Abū Bakra's lineage than scholars of other fields (63), but this is not really the case. Legal (shar' $\bar{\imath}$ ) paternity is not the same as biological paternity, in the same way that the astronomically-determined beginning of the month of Ramadān is not the same as its legal start date, according to the majority of jurists. ${ }^{18}$ The claim of the hadith scholars is thus a legal and not a historical one. In any case, this is a fascinating and well-researched chapter of the book.

Overall, then, Conquered Populations is an impressive achievement, and it deserves to be widely read. To those working on early Islam, slavery and "Arabness" (and other contested categories of identity), it is indispensable. As a piece of writing it is admirably lucid. Urban is clearly an extremely talented, thoughtful and creative scholar, and I have learned a great deal from her work. This is not to 
ignore the book's occasional blindspots which, as an academic whose home discipline is Islamic law, I do sometimes find a bit frustrating. But perfection, as the common saying has it, belongs to God alone.

OMAR ANCHASSI

Early Career Fellow in Islamic Studies University of Edinburgh, Edinburgh, UK 


\section{Endnotes}

* I thank the following (in alphabetical order) for their comments on drafts of this essay: Samy Ayoub, Usaama al-Azami, Antonia Bosanquet, Jonathan A.C. Brown, Peter Gray, Hannah Hagemann, Dženita Karić, Yossef Rapoport, Ahmed El Shamsy, Tariq al-Timimi, Elizabeth Urban, and Saadia Yacoob. Any remaining faults are very much my own.

1 'Abd al-Razzāq al-Ṣan 'ānī (d. 21 1/826), Muṣannaf 'Abd al-Razzāq, ed. Ḥabīb al-Raḥmān al-A'ẓamī, 11 vols. (Surat: al-Majlis al-'Ilmī, 1403), 7:216; Ibn al-Mundhir (d. 318/930), al-Awsaț min al-sunan wa l-ijmā' wa l-ikhtiläf, ed. Muhammad 'Abd al-Salām, 15 vols. (al-Fayyūm: Dār al-Falāḥ, 2009), 8:402.

2 Ibid. (in both of the above sources).

3 'Abd al-Razzāq, Mușannaf, 7:405. Variants add further detail to the narrative, including the fact that the woman in question was a matron (thayyib); in ordinary circumstances, she would have been stoned to death. In other reports (ibid., 405-407), 'Umar averts the hadd entirely from women who prostitute themselves to avoid dire hunger and thirst. See also the very illuminating discussion of these reports in Hina Azam, Sexual Violation in Islamic Law: Substance, Evidence, and Procedure (Cambridge: Cambridge University Press, 2015), 102-103.

4 Muhammad b. al-Ḥasan al-Ṭūsī (Shaykh al-Ṭāà ifa, d. 460/1067), al-Mabsūt fì fiqh al-Imāmiyya, ed. Muḥammad Bāqir al-Bahbūdī (Qom: al-Maktaba al-Murtaḍawiyya li-Iḥyā' al-Turāth al-Ja'fariyya, n.d.), 6:185; idem, al-Istibșār fī-mā ikhtulifa min al-akhbār (Beirut: Mu'assasat al-A'lamī, 1326/2005), 680. I thank Peter Gray for pointing me to the first of these sources.

5 Patricia Crone, "The Early Islamic World," in War and Society in the Ancient and Medieval Worlds, eds. Kurt Raaflaub and Nathan Rosenstein (Cambridge: Harvard University Press, 1999), 309-332 (at 314); Jack Tannous, The Making of the Medieval Middle East: Religion, Society, and Simple Believers (Princeton: Princeton University Press, 2018), 350.

6 To my mind, at least, there is far more mileage in Webb's claims: see esp. his Imagining the Arabs: Arab Identity and the Rise of Islam (Edinburgh: Edinburgh University Press, 2017). For criticisms of Donner, see, e.g., Patricia Crone, "Among the Believers," Tablet (August 10, 2010): tabletmag. 
com/amp/sections/israel-middle-east/articles/among-the-believers (accessed 8/10/2020); Tannous, The Making of the Medieval Middle East, 394-7; idem, "Review," Expositions 5, no. 2 (2011), 126-141. Tannous concludes (136) that Donner spins a "feel-good story... which will be met with gladness by those sharing his political ideals. It is a story, however, which is as radically revisionist as Hagarism and equally as fanciful." I can only echo Tannous' sentiments.

7 Contrast with Fred Donner, according to whom referring to the Believers' movement as "Islam" prior to the late seventh or eighth centuries would be "historically inaccurate." See Muhammad and the Believers: At the Origins of Islam (Cambridge: Harvard University Press, 2010), 195.

8 E.g. Nurit Tsafrir, Collective Liability in Islam: The 'Āqila and Blood-Money Payments (Cambridge: Cambridge University Press, 2020); Najam Haider, The Origins of the Shī'a: Identity, Ritual and Sacred Space in Eighth-Century Küfa (New York: Cambridge University Press, 2011).

9 Harald Motzki, "The Muṣannaf of 'Abd al-Razzāq al-Ṣan 'ānī as a Source of Authentic Ahädìth of the First Century A.H.," JNES 50 (1991): 1-21. Note that 'Abd al-Razzāq is the source of three of the epigraphs to this article.

10 Say, when considering the number of works, volumes, and pages from authors who lived and died in the first two and a half Islamic centuries.

11 On the early juristic disagreement on enslaving free Muslims, see e.g. Irene Schneider, "Freedom and Slavery in Early Islamic Time $[\mathrm{sic}]\left(1^{\text {st }} / 7^{\text {th }}\right.$ $-2^{\text {nd }} / 8^{\text {th }}$ Centuries)," al-Qantara 28 (2007): 353-382. The focus of my criticism here is, however, the second point. On the enslaving of Arabs and the (minority) view forbidding it, see e.g. al-Bayhaqi (d. 458/1066), al-Sunan al-kubrāa, ed. Muḥammad 'Abd al-Qādir 'Ațā, 11 vols. (Beirut: Dār al-Kutub al-'Ilmiyya, 1424/2003), 9:125-128; Ibn Taymiyya (d. 728/1328), al-Fatāwā al-kubrā, eds. Muhammad 'Abd al-Qādir 'Ațā and Mușțafā 'Abd al-Qādir 'Ațā, 6 vols. (Beirut: Dār al-Kutub al- 'Ilmiyya, 1408/1987), 3:1 15; al-Shawkānī (d. 1250/1834), Nayl al-awtāār min asrār Muntaqāa al-akhbār, ed. Muḥammad Șubḥ̄ b. Ḥasan Ḥallāq, 16 vols. (Riyadh: Dār Ibn al-Jawzī, 1427), 14:268-276 ; Muḥammad Zakariyya al-Kāndahlawī (d. 1402/1982), Awjaz al-masālik ilà Muwațta’ Mālik, ed. Taqī al-Dīn al-Nadwī, 17 vols. (Damascus: Dār al-Qalam, 1424/2003), 11:446. 
12 To give but one of innumerable examples, the Zaydī Imām al-Hādī ilā l-Ḥaqq Yahyā b. al-Ḥusayn (d. 298/911) was shocked to find that in al-A'șūm in the Yemen a host would "honour" his guest by "offering him his daughter or his sister." The Imām declared that such people were worthier targets of jihād than the Byzantines (nabda' bihim qabl jihād al-rūm). See Sìrat al-Hād̄ ila l-Haqq Yahyā b. al-Ḥusayn: riwāyat 'Alī b. Muhammad 'Ubayd Allāh al-'Abbāsī al-'Alawīe ed. Suhayl Zakkār (Beirut: n.p., 1392), 125. In his important study and edition of the Ghäyat al-amānì (another sīra-text), A.B.D.R. Eagle notes that al-Hādī "found a society in which prostitution, loose sexual morality and the imbibing of alcohol were rife." See his "Ghāyat al-amānī and the Life and Times of al-Hādī Yahyā b. al-Husayn: An Introduction, Newly Edited Text and Translation with Detailed Annotation” (PhD thesis, Durham University, 1990), 46. On the moral campaign fought by al-Hādī, see also Michael Cook, Commanding Right and Forbidding Wrong in Islamic Thought (Cambridge: Cambridge University Press, 2001), 234-235. For an anthropological account of the practice of sexual hospitality, see e.g. Walter Dostal, "Sexual Hospitality' and the Problem of Matrilineality in Southern Arabia," Proceedings of the Seminar for Arabian Studies 20 (1990): 17-30.

13 E.g. al-Kulaynī (d. 329/941), al-Kāfī, 8 vols. (Beirut: Manshūrāt al-Fajr, 1328/2007), 5:282-284; Shaykh al-Ṭā' ifa, al-Istibṣār, 537-538.

14 E.P. Thompson, The Making of the English Working Class (London: Penguin, 2013), 12.

15 In response to these observations, the author makes the following points: it is impossible to completely abstract oneself from one's worldview when doing history; the point of not condoning the Abü Bakra hadith was to prevent readers from misinterpreting her disagreement with Khaled Abou El Fadl and Fatema Mernissi as a defence of the sentiments expressed therein, and finally, that her comments on tafsīr direct readers towards the tensions in that literature, and the failures of its authors to address their own contexts.

16 Luke Yarbrough, Friends of the Emir: Non-Muslim State Officials in Premodern Islamic Thought (Cambridge: Cambridge University Press, 2019), esp. 73-84. Urban says that Qurashite Arabs likely preferred military to mundane bureaucratic posts (155); as Yarbrough explains, the common attitude to administrative affairs among the early conquest elite was that “someone else could do it" (Yarbrough, Friends, 81). 
17 In response to these observations, the author remarks that the divergent reading was a thought experiment premised on a "history from below" approach: what might the verse mean to an enslaved woman, in that context? She emphasises the importance of empathetic imagination (within certain constraints) to the historian's approach to the sources. Her work has been influenced by Joan Wallach Scott, in this respect.

18 For a brilliant discussion of this distinction (and its undoing) in the context of the career of the Egyptian state Muftī Muhammad Bakhìt al-Muțīì (d. 1354/1935), see Syed Junaid A. Quadri, "Transformations of Tradition: Modernity in the Thought of Muhammad Bakhìt al-Muṭi î̀” (PhD diss., McGill University, 2013), 111-137.

doi: 10.35632/ajis.v38i1-2.2018 